\title{
Towards a Professionalism of Agricultural Extension: Key to Promoting Extension Effectiveness in Africa
}

\author{
Robert Agunga ${ }^{1}$, Ruth Sleshi ${ }^{2}, \&$ Rahwa Hassen ${ }^{3}$ \\ ${ }^{1}$ College of Food, Agricultural, and Environmental Sciences, The Ohio State University, Columbus, Ohio, USA \\ ${ }^{2}$ College of Arts and Sciences, The Ohio State University, Columbus, Ohio, USA \\ ${ }^{3}$ College of Public Health, The Ohio State University, Columbus, Ohio, USA
}

Correspondence: Robert Agunga, College of Food, Agricultural, and Environmental Sciences, 201 Agricultural Administration Building, 2120 Fyffe Road, Columbus, OH 43210, USA. Tel: 614-292-8751. E-mail: agunga.1@osu.edu

Received: November 9, 2016 Accepted: February 20, 2017 Online Published: March 18, 2017

doi:10.5539/sar.v6n2p81 URL: https://doi.org/10.5539/sar.v6n2p81

\begin{abstract}
A survey of a small sample of 123 extension workers in Ghana and Ethiopia may have revealed the key issue facing extension ineffectiveness in Africa - the paucity of extension training. Questions on job satisfaction showed that respondents were highly satisfied with: a) an opportunity to work in an area they are trained $(\mathrm{N}=88$, $57 \%), b)$ level of education ( $\mathrm{N}=75(61 \%)$, c) enthusiasm towards their work ( $\mathrm{N}=72(58.5 \%)$, and d) opportunity to work with local farmers. However, they were highly dissatisfied with: a) their salaries $(\mathrm{N}=108(87.8 \%), \mathrm{b})$ the process of decentralization $(\mathrm{N}=83(75.6 \%), \mathrm{c})$ cooperation from non-governmental agencies $(\mathrm{N}=87(70.7 \%), \mathrm{d})$ respect from peers in other sectors of government $(\mathrm{N}=83(68.0 \%)$, e) training in development $(\mathrm{N}=79(65.3 \%)$, and $\mathrm{f}$ ) training in communication $(\mathrm{N}=65(54.2 \%)$. We find their complaints on lack of or limited training in development and communication worthy to note because in the last 40 years extension performance has stressed facilitation among development partners. It can be argued, therefore, that the slow process of decentralization, the friction between extension workers and their NGO counterparts, and their inability to get along with their compatriots in other ministries can be traced to their limited or lack of training in development and communication, otherwise called "Communication for Development" (C4D). We conclude, therefore, that if extension workers are to be effective in their new role as development facilitators not only must their training in agriculture expand to include C4D but, equally significant, extension systems throughout the continent must operate as a profession. Therefore, the authors recommend the establishment of a professional association throughout Africa, under the rubric of "ExtensionAfrica," which will address the need for extension effectiveness on the continent. We particularly recommend a collaborative relationship with the African Forum for Agricultural Services (AFAAS), which has a mandate for advising on extension services, to make this happen.
\end{abstract}

Keywords: agricultural education and extension, agricultural extension in Africa, extension and communication, extension policy and reform, extension professionalism, pluralistic and demand driven extension, communication for development, and transforming agriculture in Africa

\section{Introduction}

The United Nations estimates that the world population will be roughly 10 billion by 2050 and most of the projected increase will be in Africa where fertility rates show no sign of declining. The World Bank's Poverty in a Rising Africa Report (2016) noted that although the share of Africa's population in extreme poverty declined from 56 percent in 1990 to 43 percent in 2012, rapid population expansion actually increased resulting in more than 100 million people living in extreme poverty.

Smallholder farmers account for over 70 percent of the population of African countries, therefore, it goes without saying that for Africa to feed itself, productivity in the subsistence sector must double or even triple. Estimates, indicate these farmers are only producing at a third of their capacity thus the potential to increase productivity exists. The challenge is whether extension can assist them in gaining access to modern farming techniques and technologies. The centrality of agricultural extension in transforming subsistence agriculture is sine qua non.

The problem is that 60 years of the existence of agricultural extension systems in Africa, many dating back to 
colonial times, has not yielded the desired impact. The result is that laudable policy initiatives, such as the Comprehensive African Agriculture Program (CAADP) and the Maputo Declaration that urge African governments to increase spending in the sector to stimulate agricultural growth, reduce poverty, and build food and nutrition security, will not have the desired impact. Criticism of extension in Africa and throughout the developing world is evident everywhere one looks. Davidson and Ahmad (2003) note that public extension systems have failed to meet the needs and problems of farmers. Oyaro adds that Sub-Saharan Africa is characterized by an "extension work sector that is failing to make the grade" $(2010$, p. 2). Also, 20 years of experimentation have shown that private extension systems have been just as ineffective as public extension institutions in meeting the needs of smallholder farmers (RUTATORA \& Mattee, 2001; Ronald, Dulle \& Honesta, 2014).

These weaknesses notwithstanding, African governments and donor agencies still recognize extension as a "formidable force" in the fight against "hunger and rural poverty" and continue to invest in extension (Qamar, 2005, p. v). Thus, the question is not whether extension, especially public sector extension, is needed in Africa but rather, how it can be made more effective? This study of extension workers in Ghana and Ethiopia focused on: the teething challenges facing extension in Africa and whether the time is ripe for establishing a professionalism of extension in Africa to enhance its extension effectiveness by addressing competencies needed for the profession.

\section{Towards a Professionalism of Extension in Africa}

Professionals profess meaning that, no matter the task, they are able to perform better than non-professionals. A profession of extension in Africa means that this organization can assist smallholder farmers increase productivity by identifying and tackling the complexities of problems impacting productivity. It is a well-known fact that problems, such as markets, inputs, and transportation are handled by organizations outside agriculture yet their participation in extension programming is necessary for ensuring farmers' productivity. The challenge is whether the training of extension workers prepares them to examine their role from a system's perspective.? Extension workers, it would seem, must be up-to-date with changing donor policies, guidelines, and fads. For example, under the Paris declaration of 2005 major bilateral aid countries, such as the U.S., UK, The Netherlands, and other G8 nations, agreed to lesion the strings on aid. By the same token, under the Accra Agenda for Action (AAA) meeting in Accra, Ghana in 2008, African governments accepted responsibility for ensuring aid effectiveness. Yet, it is doubtful how many extension systems in Africa are familiar with these policies let alone practicing them. In a similar vein, the outgoing US President, Mr. Obama, during his visits to Ghana and Tanzania in 2009 and 2013 respectively, said that the development of Africa rests with Africans themselves. Outsiders, he noted, can help but it is the Africans who can decided on the nature of development they aspire and the nature of assistance they want from outsiders. Yet, it is unsettling to listen to top officials of some African countries complain about the strategies of some donor agencies as if they are helpless in challenging these donors to change their ways.

Our argument is that extension is at the heart of African development. All aid meant for smallholder farmers, in the final analysis, is channeled through extension. Therefore, how extension workers understand and manage the aid relationship at the grassroots is critical to development. Many governments receive multimillion dollar grants or soft loans for agricultural development yet none of this goes into loans or credit for smallholder farmers. yet However, it is a well-known fact that without loans these farmers cannot adopt productivity innovations no matter how much they like to.

It would seem to us, therefore, that an effective extension system in Africa must be pro-active towards change by making demands on governments and donors on behalf of their farmers and not wait to be told what to do.

\section{Purpose of the Study}

This study of a convenient sample of 123 extension practitioners - 49 in Ghana and 74 in Ethiopia - was conducted to elicit their views on whether there is a need to establish a professional extension organization in Africa. Chapman defined a profession as "a body of trained specialists [which] has as its primary, general, or professional objective of service to society" (1990, p. 14). He conceived the ethics of a profession as:

Those principles of conduct that ensure the faithful performance of this service, and as such establish the reputation of the profession, extend its influence, and multiply its opportunities for service. The reaction from this benefits the profession itself, increases the opportunities for employment and the salary scale, and makes the profession more desirable (p. 14).

Chapman wrote in the 1920s on the need for a profession of forestry. However, his definition applies to the need 
for a profession of extension in the $21^{\text {st }}$ century on three grounds. First, extension has a commitment to serve society by increasing food supply through helping farmers adopt innovative practices. Therefore, it would seem that the yardstick for measuring extension effectiveness is increased annual yields, especially, in the subsistence sector. Pre-test/post-test measures should generate empirical evidence to show if farmers are producing more (Smith, 2004). Second, what constitutes the body of knowledge for extension must be appraised and incorporated into the curricula for extension workers. Is it a study of agriculture, communication or development or a combination of these? West, Drake and Londo (2009) and Davidson and Ahmad (2003) stress knowledge of communication theory and skills; Röling (1972) and Röling and Jiggins (2007) emphasize knowledge of the social sciences at large; and Rondinelli (1993) highlighted the need for an understanding of the increasing complexity of agricultural and rural development programming. Others stress the need for empiricism, that is, using pre-post measures to determine the effectiveness of extension (Inagaki, 2007). Thus, the questions of interest to the researchers were: First, is a professional extension association in Africa needed to outline the competencies for the profession? Second, what services will provide members with satisfaction, considering salaries are woefully low and will remain so for a long time? And third, can extension workers, especially those at the grassroots, afford membership fees?

\section{Keys to a Successful Professional Organization}

A professional, as typified by the medical practitioner, nurse or engineer, is someone who can get the job done to his or her maximum potential. Thus, this begs the question: Can agricultural extension in Africa be a profession? Does extension meet the criteria of a profession as outlined by Broderick (2016) and Lindblad (n.d.) below?

a. A specialized knowledge base that is kept up-to-date: Research findings in a given field provide new knowledge and the consummate professional must be in tune with this knowledge in order to deliver the best work possible.

b. Competency or the ability to get the job done: Knowledge and skills go together as a skill is the competency to apply knowledge.

c. Honesty and integrity: These are the cardinal goals of a profession. Extension worker's appointments with farmers must be honored in a timely manner. Likewise, integrity means that extension workers must not use public time for private gains.

d. Self-regulation: This means staying focused under pressure. The extension worker should not get into arguments with farmers or colleagues.

e. Showing respect: Genuine extension professionals show respect for stakeholders and the general public. The extension worker is a leader and leaders show respect to whomever they interact with, namely, their NGO counterparts.

f. Image: Lastly, true extension professionals must dress appropriately to exude an air of confidence and to command respect.

The Ministry of Agriculture, Forestry and Fisheries (2011) in South Africa is injecting professionalism in its extension service under the "five pillars" of its Extension Recovery Program (ERP). The pillars are: a) ensuring visibility and accountability of extension; b) promoting professionalism and improving image; c) recruiting extension personnel, d) reskilling and reorienting extension, and e) providing information communication and technologies (ICTs) and other resources. South Africa's effort is timely and should provide lessons for other African countries (Zwane, 2014).

Norton (2010) identified "10 things that define a true professional," which are: 1) putting customer satisfaction first, 2) making expertise a specialty, 3) doing more or exceeding expectations; 4) talking the talk and walking the walk (delivering on promises made); 5) communicating effectively, 6) following guiding principles, 7) showing respect and acknowledging efforts of peers, 8) sharing knowledge, 9) remembering to say thank you to others for their help, and 10) always wearing a smile even when you are miserable or unhappy inside.

A professionalism of extension in Africa must address these concerns, bearing in mind that the reward for extension will come only with increased smallholder farmer productivity. Many extension workers excel in several of these characteristics, such as respecting peers and wearing a smile. However, putting customers first and delivering on promises are major concerns.

\section{Statement of Research Objectives}

The research objectives for the study were as follows:

1. To examine challenges facing a professionalism of extension in Africa by reviewing the demographic 
characteristics of extension workers;

2. To examine factors that will promote job satisfaction for extension professionals;

3. To review the training needs of extension professionals; and

4. To examine the competencies or skills set required of extension professionals.

\section{Methodology}

The methodology for this study was survey research using purposive or convenient sampling. Forty-nine (49) extension practitioners were drawn from the Upper East Region of Ghana and 74 from the Gondar Region of Ethiopia. The sample sizes are too small for generalizability to extension workers in either country or to both countries (Schiffman \& Kanuk, 1997). Thus, our goal is not generalization but rather to provide a bird's eye-view on the perceptions of extension workers regarding the need for extension professionalism in Africa. Data was collected in July and August 2015 and analyzed using SPSS.

\section{Results}

\subsection{Demographic Characteristics}

Demographic data help us to understand the characteristics of individuals in the study, which can point to challenges facing extension. For example, knowing that the majority of extension workers have been in the field for over 20 years may suggest the need for more training, especially in farming innovations and development concepts introduced in the last decade or so. Therefore, demographic data is important. As noted earlier, the study comprised of 123 respondents: 49 (39.8\%) from Ghana and 74 (60.2\%) from Ethiopia. Forty-three (35.0\%) respondents reported living in rural areas, $26(21.1 \%)$ lived in urban areas, and $37(30.1 \%)$ lived in sub-urban areas. However, $69(56.1 \%)$ reported working in rural areas, $6(4.9 \%)$ worked in urban areas, while $26(21.1 \%)$ worked in sub-urban areas. With respect to gender, $46(37.4 \%)$ were female and $72(58.5 \%)$ were male. Years of experience refer to how long one has worked as an extension agent. Twenty-six $(21.1 \%)$ worked for 2 years or less, 25 (20.3\%) worked 3-5 years, 35 (28.5\%) had 6-10 years of experience, 6 had 11-15 years of experience, 17 $(13.8 \%)$ worked $16-20$ years, and $14(11.4 \%)$ had 26 or more years of experience. Overall, $30 \%$ had 11 years of experience or more while $60 \%$ had six years or more of experience. Thus, it can be said that many of the respondents were highly experienced or have been in the field for a relatively long time and, therefore, would need refresher training.

With respect to education, 25 (20.3\%) had certificate level training, 56 (45.5\%) had diploma level training, 40 $(32.5 \%)$ had bachelor degree level training, and one had a Master's degree. In general, $66 \%$ of respondents had education below the bachelor degree level. About 58 respondents (47\%) achieved their highest degree five years ago or less, 45 (36.6\%) obtained their highest degree 6-15 years ago and $15(12.2 \%)$ mentioned 16 or more years ago.

\subsection{Extension Workers' Exposure to Information and Communication Technologies}

Today, inclusion of information and communication technologies (ICTs) in extension is strongly advocated though the impact of these tools on extension success remains unclear (Lwoga \& Ngulube, 2008; Mittal, Gandhi, \& Tripath, 2010). Gholami, Higon, Hanafizadeh and Emrouznejad (2010) reviewed the role of ICTs in poverty reduction and sustainable development programs and concluded that there is hardly any relationship between ICTs use and productivity growth in developing countries. However, they also concluded that ICTs have an impact on human development index scores for less developed countries without clarifying what this means. In any case, extension agents in developing countries crave for ICTs thus our goal was to examine whether they have these tools in the first place. We asked extension workers whether they a) owned, b) had access or c) did not own (or had no access to) ICTs? Table 1 shows our findings. The significant findings were that roughly $80 \%$ of respondents either owned or had access to television; more than $80 \%$ either owned or had access to a cell phone and more than half of them did not have access to computers either at home or in the office. Surprisingly, a significant number of respondents had Facebook pages, Skype Addresses and Web Sites. Equally surprising is that the use of these ICTs was not being applied in extension work, perhaps because the technologies were not supplied through the Ministries. 
Table 1. Extension Workers' Access to Social and Mass Media

\begin{tabular}{llll}
\hline Type of medium & Own & Have Access & Do not own or have access \\
\hline Television at home. & $75(61.0 \%)$ & $20(16.3 \%)$ & $14(11.4 \%)$ \\
Telephone in the office. & $8(6.5 \%)$ & $11(8.9 \%)$ & $84(68.3 \%)$ \\
Cell phone & $93(75.6 \%)$ & $11(8.9 \%)$ & $3(2.4 \%)$ \\
Computer in the office. & $7(5.7 \%)$ & $33(26.8 \%)$ & $65(52.8 \%)$ \\
Computer/Laptop at home. & $26(21.1 \%)$ & $13(10.6 \%)$ & $65(52.8 \%)$ \\
Access to Internet in the Office. & $7(5.7 \%)$ & $12(9.8 \%)$ & $83(67.5 \%)$ \\
Access to Internet in Café. & $22(17.9 \%)$ & $35(28.5 \%)$ & $47(38.2 \%)$ \\
Radio set. & $81(65.9 \%)$ & $16(13.0 \%)$ & $11(8.9 \%)$ \\
Facebook page. & $46(37.4 \%)$ & $28(22.8 \%)$ & $31(25.2 \%)$ \\
Skype address. & $15(12.2 \%)$ & $17(13.8 \%)$ & $67(54.5 \%)$ \\
Web site. & $19(15.4 \%)$ & $20(16.3 \%)$ & $67(54.5 \%)$ \\
\hline
\end{tabular}

\subsection{Job Satisfaction}

It is a well-known fact that the salaries of extension workers in developing counties are extremely low. For example, it is stated that extension workers in NGOs in Malawi were being paid $\$ 700$ per month while their counterparts in the Ministry of Agriculture and Food Security received only $\$ 100$ per month (Future Agricultures, 2010). Therefore, salary may not be an incentive or may not serve as an indicator of job satisfaction. Belay and Abebaw (2004) noted that a major problem of extension in developing countries is the absence of clearly defined systems of reward and penalty. In other words, reward and incentive systems, which will attract, retain, and motivate extension personnel are either poor or totally lacking. Vijayaragavan and Singh (1997) added that in many countries reward systems are based primarily on seniority, not merit. So, many people come to the workplace with varying expectations. For example, some people may be content with job security, that is, knowing that their jobs are not going anywhere even though the pay may be low. Also, there is an ongoing debate between job satisfaction and job performance, that is, do satisfied workers produce more? Our answer would be "yes" even though it is not empirically founded. This study asked extension workers what factors gives them job satisfaction (as shown in Table 2). Many respondents noted that the opportunity to work in an area they were trained in gives them satisfaction. Others also derived satisfaction from their enthusiasm for the job. Still others derived satisfaction from the opportunity they have to work with farmers.

Table 2. Job Satisfaction of Extension Workers

\begin{tabular}{lcccc}
\hline \multicolumn{1}{c}{ Job Satisfaction } & \multicolumn{2}{c}{ Dissatisfied } & \multicolumn{2}{c}{ Satisfied } \\
& $\mathrm{N}$ & $\mathrm{SD}$ & $\mathrm{N}$ & $\mathrm{SD}$ \\
\hline 1. Opportunity to work in an area I am trained in. & 31 & $26.1 \%$ & 88 & $57.2 \%$ \\
2. Enthusiasm towards my work. & 48 & $40.0 \%$ & 72 & $60.0 \%$ \\
3. Opportunity to work with the local farmers. & 51 & $41.5 \%$ & 72 & $58.5 \%$ \\
4. Salary and other incentives related to my work. & 108 & $87.8 \%$ & 15 & $12.2 \%$ \\
5. The speed of decentralizing extension services to the districts. & 93 & $75.6 \%$ & 30 & $24.4 \%$ \\
6. Respect I get from my peers in other sectors of government. & 83 & $68.0 \%$ & 39 & $32.0 \%$ \\
7. My training in communication. & 65 & $54.2 \%$ & 55 & $45.8 \%$ \\
8. My training in development theory/policy and practice. & 79 & $65.3 \%$ & 42 & $34.7 \%$ \\
9. Cooperation I get from non-governmental organizations. & 87 & $70.7 \%$ & 36 & $29.3 \%$ \\
10. Cooperation I get from various organizations in the Ministry of Agriculture. & 70 & $56.9 \%$ & 53 & $43.1 \%$ \\
11. My level of education. & 30 & $25.0 \%$ & 75 & $61.0 \%$ \\
12. Resources I have to work with. & 78 & $63.4 \%$ & 30 & $24.4 \%$ \\
13. Opportunities I have for higher education. & 50 & $40.7 \%$ & 53 & $43.0 \%$ \\
14. Opportunities for short-term, in-service training. & 48 & $40.0 \%$ & 61 & $49.6 \%$ \\
15. Membership in a professional extension organization. & 45 & $36.5 \%$ & 61 & $49.6 \%$ \\
16. Opportunity to be recognized across Africa. & 70 & $57.0 \%$ & 37 & $30.1 \%$ \\
\hline
\end{tabular}

Note. Means were calculated from a scale of 1 = Very Highly Dissatisfied (VHD); 2 = Highly Dissatisfied (HD);

3 = Dissatisfied (D); 4 = Satisfied (S); 5 = Highly Satisfied (HS); 6 = Very Highly Satisfied (VHS).

However, there are many things that give extension workers dissatisfaction. Top on the list are salaries and other 
incentives related to the job. One hundred and eight respondents $(87.8 \%)$, or the overwhelming majority, were dissatisfied with their salaries. A large majority, 93 respondents (75.6\%), were also dissatisfied with the speed of decentralization of extension services while $79(65.3 \%)$ were dissatisfied with their training in development theory/policy and practice.

\subsection{Extension/Farmer Contact}

Extension/Farmer contact is the degree to which the extension worker is communicating with the farmer. It can occur face-to-face, via radio, print or through social media. The degree of extension/farmer contact is affected by the farmers-to-agent ratio. On a face-to-face basis, more farmers mean less extension contact. However, using community radio or other forms of mass media can ensure the extension agent reaches more farmers. Extension workers were asked how many farmers they were responsible for. The numbers varied. Seventy-three (59.3\%) respondents said their farmers numbered 2,000 or less. Fifteen (12.2\%) mentioned 3-5, 000, 14 (11.4\%) said 6-10,000, three (2.4\%) mentioned 11-15,000, and 7 (5.7\%) said over 15,000 farmers. When asked how many of their farmers they visited last year one person said hardly any and another said less than $1 \%$. However, 81 respondents $(65.9 \%)$ said more than 50\% and $17(13.9 \%)$ said about 5-10\%. Nineteen respondents (15.4\%) said they visited all of their farmers. However, when we asked how many of their farmers visited them the responses seemed exaggerated. Forty-one (41) respondents (33.3\%) said more than 50\% of their farmers visited them. Another 52 respondents $(42.2 \%)$ said $5-10 \%$ of their farmers visited them, and 16 respondents $(13.0 \%)$ said all their farmers visited them. When asked their primary means of contact with farmers 110 respondents (89.4\%) said face-to-face. One person mentioned email and five, said radio. Seven extension workers mentioned "other" but did not specify.

\subsection{Communication Skills and Training Needs}

Communication skills refer to the many ways a person can express himself or herself in order to be understood. The spoken word is one form of communication skills. The written word, video production, and radio are other types of communication skills the extension worker can use. Respondents were asked to indicate their training needs related to various communication skills; Table 3 presents our findings. To the left, respondents identified skills vital or important to their work. Key among them were public speaking, listening, writing, promoting collaboration and linkage, conducting baseline studies, media relations, using PowerPoint, and computer literacy. To the right, respondents indicated their abilities to perform these functions. Many respondents felt that they were deficient to severely deficient in performing functions such as promoting linkage, media relations, use of PowerPoint, and computer literacy. However, many respondents felt that they were proficient to highly proficient in public speaking, writing, and listening. However, they also said that they were proficient to highly proficient in promoting communication for development, people involvement, community-driven development, integrated rural development, and assessing extension impact. It would seem, however, that many of these claims may be inflated due to the lack of comprehension of specific terms or the refusal to admit a lack in skills. For example, communication for development is concept many communication scholars have a problem grasping; it is surprising, therefore, that extension workers say they know what it is.

Similarly, it is surprising that extension workers claim they are promoting participation, community-driven development, and integrated rural development when the literature is filled with claims that these are not being done (Rondinelli, 1993; Amoako-Tuffour \& Armah, 2008). These contradictions demonstrate one of the weaknesses of survey research: sometimes people refuse to acknowledge what they don't know. It may also be an error on the researchers' part for not finding alternative ways of asking the question. 
Table 3. Gap between Communication Skills Needed by Extension Workers and Performance Levels

\begin{tabular}{|c|c|c|c|c|c|c|c|c|c|c|c|c|c|c|c|c|}
\hline \multicolumn{2}{|c|}{$\begin{array}{l}\text { Not } \\
\text { Important }\end{array}$} & \multicolumn{2}{|c|}{$\begin{array}{l}\text { Somewhat } \\
\text { Important }\end{array}$} & \multicolumn{2}{|c|}{$\begin{array}{l}\text { Critically } \\
\text { Important }\end{array}$} & \multicolumn{2}{|c|}{$\begin{array}{l}\text { Severely } \\
\text { Important }\end{array}$} & \multirow{2}{*}{$\begin{array}{l}\text { Skill } \\
\text { Public speaking }\end{array}$} & \multicolumn{2}{|c|}{$\begin{array}{l}\text { Highly } \\
\text { Deficient }\end{array}$} & \multicolumn{2}{|c|}{ Deficient } & \multicolumn{2}{|c|}{ Proficient } & \multicolumn{2}{|c|}{$\begin{array}{l}\text { Highly } \\
\text { Proficient }\end{array}$} \\
\hline 2 & $1.6 \%$ & 6 & $4.9 \%$ & 64 & $52.0 \%$ & 47 & $38.2 \%$ & & 4 & $3.3 \%$ & 13 & $10.6 \%$ & 79 & $64.2 \%$ & 21 & $17.1 \%$ \\
\hline 4 & $3.3 \%$ & 9 & $7.3 \%$ & 61 & $49.6 \%$ & 46 & $37.4 \%$ & Writing & 5 & $4.1 \%$ & 7 & $5.7 \%$ & 70 & $56.9 \%$ & 36 & $29.3 \%$ \\
\hline 4 & $3.3 \%$ & 4 & $3.3 \%$ & 53 & $43.1 \%$ & 56 & $45.5 \%$ & Listening & 2 & $1.6 \%$ & 0 & $0 \%$ & 66 & $53.7 \%$ & 48 & $39.0 \%$ \\
\hline 1 & $0.8 \%$ & 10 & $8.1 \%$ & 52 & $42.3 \%$ & 55 & $44.7 \%$ & $\begin{array}{l}\text { Communication } \\
\text { planning }\end{array}$ & 6 & $4.9 \%$ & 12 & $9.8 \%$ & 73 & $59.3 \%$ & 25 & $20.3 \%$ \\
\hline 1 & $0.8 \%$ & 11 & $8.9 \%$ & 65 & $32.8 \%$ & 40 & $32.5 \%$ & Baseline studies & 5 & $4.1 \%$ & 32 & $26.0 \%$ & 63 & $51.2 \%$ & 14 & $11.4 \%$ \\
\hline 2 & $1.6 \%$ & 8 & $6.5 \%$ & 55 & $44.7 \%$ & 49 & $39.8 \%$ & $\begin{array}{l}\text { Promoting } \\
\text { collaboration }\end{array}$ & 7 & $5.7 \%$ & 29 & $23.6 \%$ & 60 & $48.8 \%$ & 22 & $17.9 \%$ \\
\hline 2 & $1.6 \%$ & 9 & $7.3 \%$ & 50 & $40.7 \%$ & 53 & $43.1 \%$ & Linkage & 15 & $12.2 \%$ & 27 & $22.0 \%$ & 54 & $43.9 \%$ & 21 & $17.9 \%$ \\
\hline 3 & $2.4 \%$ & 29 & $23.6 \%$ & 51 & $41.5 \%$ & 31 & $25.2 \%$ & Media relations & 20 & $16.3 \%$ & 40 & $32.5 \%$ & 35 & $28.5 \%$ & 20 & $16.3 \%$ \\
\hline 3 & $2.4 \%$ & 14 & $11.4 \%$ & 53 & $43.1 \%$ & 43 & $35.0 \%$ & Lobbying/Advocacy & 7 & $5.7 \%$ & 39 & $31.7 \%$ & 48 & $39.0 \%$ & 22 & $17.9 \%$ \\
\hline 6 & $4.9 \%$ & 25 & $20.3 \%$ & 48 & $39.0 \%$ & 39 & $31.7 \%$ & PowerPoint use & 23 & $18.7 \%$ & 38 & $30.9 \%$ & 39 & $31.7 \%$ & 19 & $15.4 \%$ \\
\hline 1 & $0.8 \%$ & 5 & $4.1 \%$ & 58 & $47.2 \%$ & 53 & $43.1 \%$ & $\begin{array}{l}\text { Communication for } \\
\text { development }\end{array}$ & 1 & $0.8 \%$ & 21 & $17.1 \%$ & 75 & $61.0 \%$ & 20 & $16.3 \%$ \\
\hline 10 & $8.1 \%$ & 17 & $13.8 \%$ & 50 & $40.7 \%$ & 41 & $33.3 \%$ & Computer literacy & 25 & $20.3 \%$ & 36 & $29.3 \%$ & 42 & $34.1 \%$ & 13 & $10.6 \%$ \\
\hline 2 & $1.6 \%$ & 7 & $5.7 \%$ & 64 & $52.0 \%$ & 42 & $34.1 \%$ & $\begin{array}{l}\text { Assessing extension } \\
\text { impact }\end{array}$ & 11 & $8.9 \%$ & 12 & $9.8 \%$ & 67 & $54.5 \%$ & 27 & $22.0 \%$ \\
\hline 7 & $5.7 \%$ & 16 & $13.0 \%$ & 58 & $47.2 \%$ & 31 & $25.2 \%$ & $\begin{array}{l}\text { Grant } \\
\text { writing/Fundraising }\end{array}$ & 11 & $8.9 \%$ & 38 & $30.9 \%$ & 50 & $40.7 \%$ & 16 & $13.0 \%$ \\
\hline 2 & $1.6 \%$ & 11 & $8.9 \%$ & 46 & $37.4 \%$ & 57 & $46.3 \%$ & People involvement & 2 & $1.6 \%$ & 14 & $11.4 \%$ & 59 & $48.0 \%$ & 41 & $33.3 \%$ \\
\hline 2 & $1.6 \%$ & 5 & $4.1 \%$ & 51 & $41.5 \%$ & 53 & $43.1 \%$ & $\begin{array}{l}\text { Community-driven } \\
\text { development }\end{array}$ & 3 & $2.4 \%$ & 28 & $22.8 \%$ & 63 & $51.2 \%$ & 20 & $16.3 \%$ \\
\hline 0 & $0 \%$ & 6 & $4.9 \%$ & 49 & $39.8 \%$ & 59 & $48.0 \%$ & $\begin{array}{l}\text { Integrated } \\
\text { development }\end{array}$ & 11 & $8.9 \%$ & 21 & $17.1 \%$ & 60 & $48.8 \%$ & 23 & $18.7 \%$ \\
\hline 2 & $1.6 \%$ & 1 & $0.8 \%$ & 32 & $26.0 \%$ & 59 & $48.0 \%$ & Teaching agriculture & 3 & $2.4 \%$ & 5 & $4.1 \%$ & 45 & $36.6 \%$ & 52 & $42.3 \%$ \\
\hline
\end{tabular}

\subsection{Need for a Professionalism of Extension in Africa}

Why the professionalism of extension in Africa? Qamar (2005) answers the question by stating that there is a global pressure on extension to perform better. Qamar writes, "there is a fresh and firm resolve worldwide to fight the menaces of hunger and rural poverty" and "extension workers, no matter whether they belong to government departments, NGOs, primate institutions or farmers' associations, can constitute a formidable force in this fight" $(2005, \mathrm{p}$. v). We asked extension workers on their interest in belonging to an agricultural extension profession, as shown in Table 4. There was overwhelming agreement that extension constitutes the engine of agricultural and national development as indicated by 106 respondents $(85.6 \%)$ respondents. Therefore, an organized extension system may be able to contribute significantly to the development of African nations. 
Table 4. Extension workers' interest in a professionalism of extension in Africa

\begin{tabular}{|c|c|c|c|c|}
\hline Item & Strongly Agree & Agree & $\begin{array}{l}\text { Strongly } \\
\text { Disagree }\end{array}$ & Disagree \\
\hline $\begin{array}{l}\text { 1. Extension professionals are the engines of agricultural and national } \\
\text { development. }\end{array}$ & $72(58.5 \%)$ & $34(27.6 \%)$ & $2(1.6 \%)$ & $1(.8 \%)$ \\
\hline 2. It is possible to share best practices across the continent. & $62(50.4 \%)$ & $47(38.2 \%)$ & $8(6.5 \%)$ & $4(3.2 \%)$ \\
\hline 3. The Internet makes the formation of such an organization possible. & $51(41.4 \%)$ & $50(40.7 \%)$ & $15(12.2 \%)$ & $4(3.2 \%)$ \\
\hline 4. Being recognized by my peers for good work gives me satisfaction. & $48(39.0 \%)$ & $58(47.2 \%)$ & $3(2.4 \%)$ & $0(0.0 \%)$ \\
\hline 5. Organization will give extension workers the recognition they deserve. & $45(36.5 \%)$ & $62(50.4 \%)$ & $8(6.5 \%)$ & $3(2.4 \%)$ \\
\hline 6. I will be interested in joining a professional extension organization. & $44(35.8 \%)$ & $27(2.0 \%)$ & $4(3.3 \%)$ & $0(0.0 \%)$ \\
\hline 7. I will be willing to serve in a leadership role if asked. & $43(37.0 \%)$ & $51(41.5 \%)$ & $14(11.4 \%)$ & $0(0.0 \%)$ \\
\hline 8. I can get access to ExtensionAfrica website. & $39(31.7 \%)$ & $51(41.5 \%)$ & $10(8.1 \%)$ & $20(16.3 \%)$ \\
\hline $\begin{array}{l}\text { 9. Receiving a certificate of membership is a good incentive for me to } \\
\text { become a member. }\end{array}$ & $38(30.9 \%)$ & $49(39.8 \%)$ & $9(7.3 \%)$ & $25(20.3 \%)$ \\
\hline $\begin{array}{l}\text { 10. Being a member of ExtensionAfrica will give me pride as an } \\
\text { extension professional. }\end{array}$ & $38(30.9 \%)$ & $51(41.5 \%)$ & $15(12.2 \%)$ & $17(13.8 \%)$ \\
\hline 11. I will sign up if membership becomes available. & $37(30.0 \%)$ & $59(48.0 \%)$ & $10(8.1 \%)$ & $2(1.6 \%)$ \\
\hline 12. Extension professionals must take charge of our own destiny. & $35(28.5 \%)$ & $53(43.1 \%)$ & $13(10.6 \%)$ & $4(3.2 \%)$ \\
\hline $\begin{array}{l}\text { 13. Membership will allow extension professionals across the continent } \\
\text { to speak with a common voice. }\end{array}$ & $33(26.8 \%)$ & $61(49.6 \%)$ & $7(5.7 \%)$ & $8(6.6 \%)$ \\
\hline 14. I have access to the Internet and can be connected. & $31(25.1 \%)$ & $43(35.0 \%)$ & $21(17.1 \%)$ & $14(11.4 \%)$ \\
\hline $\begin{array}{l}\text { 15. Receiving two copies of ExtensionAfrica magazine every year is a } \\
\text { good incentive for me to become a member. }\end{array}$ & $24(19.5 \%)$ & $66(53.7 \%)$ & $23(18.7 \%)$ & $7(5.7 \%)$ \\
\hline $\begin{array}{l}\text { 16. Receiving } 200 \text { business cards every two years is a good incentive for } \\
\text { me to become a member. }\end{array}$ & $21(9.8 \%)$ & $61(49.6 \%)$ & $23(18.7 \%)$ & $16(13.0 \%)$ \\
\hline $\begin{array}{l}\text { 17. As a grassroots extension practitioner I can pay } \% 50 \text { every two years } \\
\text { (in local currency) as membership. }\end{array}$ & $12(9.8 \%)$ & $29(23.6 \%)$ & $46(37.4 \%)$ & $21(17.1 \%)$ \\
\hline $\begin{array}{l}\text { 18. Higher level extension professionals should pay progressively higher } \\
\text { membership fees. }\end{array}$ & $24(19.5 \%)$ & $45(36.6 \%)$ & $24(19.5 \%)$ & $15(12.2 \%)$ \\
\hline 19. I have access to a computer. & $22(17.9 \%)$ & $28(22.8 \%)$ & $35(28.5 \%)$ & $20(16.2 \%)$ \\
\hline 20. Money is the only recognition I need. & $15(12.2 \%)$ & $29(23.6 \%)$ & $34(27.6 \%)$ & $31(25.2 \%)$ \\
\hline
\end{tabular}

Respondents felt there are many benefits to organizing. First, it will give extension practitioners the recognition they deserve. Second, members will be able to share experiences via various platforms such as the Internet. Our study found that at the moment, many extension workers do not own or have access to computers. However, as the prices of computers drop ownership will increase and so will internet access. Additionally, extension workers are willing to play leadership roles if assigned. Above all, even grassroots extension workers felt they would be able to afford the membership fees. Nearly $40 \%$ of respondents indicated an ability to pay a member ship of $\$ 50$ for two years. Surprisingly, 65 respondents (or 52.8\%) disagreed or strongly disagreed that money is the only recognition they need.

\subsection{Why a Professionalism of Extension?}

Agricultural extension in developing countries face many challenges, which requires that extension workers view their work from a holistic perspective. This implies that they will have to deal with a plethora of issues, such as pest and diseases, markets, the HIV/AIDS epidemic, credit and other inputs. These aforementioned challenges suggest the high expectation placed upon extension workers; however, investments in extension systems have not paid off. In this study we asked extension workers if they agreed with the statements in Table 5. 
Table 5. Extension workers' views on why a professionalism of extension is needed

\begin{tabular}{|c|c|c|c|}
\hline Statement & Agree & Disagree & Not Sure \\
\hline 1. A professional organization will improve our performance. & $88(71.5 \%)$ & $16(13.0 \%)$ & $5(4.1 \%)$ \\
\hline 2. Financial support for extension has declined. & $82(66.7 \%)$ & $22(17.9 \%)$ & $5(4.1 \%)$ \\
\hline 3. Extension practitioners do not get the attention they deserve. & $75(61.0 \%)$ & $27(22.0 \%)$ & $6(4.9 \%)$ \\
\hline 4. A professional organization will protect our interest. & $69(56.1 \%)$ & $29(23.6 \%)$ & $11(8.9 \%)$ \\
\hline 5. Privatizing extension is a sign of distrust of public sector extension. & $66(53.7 \%)$ & $24(19.5 \%)$ & $17(13.8 \%)$ \\
\hline 6. Extension workers receive little respect as professionals. & $64(52.0 \%)$ & $38(30.9 \%)$ & $6(4.9 \%)$ \\
\hline 7. African governments have little faith in extension. & $58(47.2 \%)$ & $31(25.2 \%)$ & $20(16.3 \%)$ \\
\hline 8. International donors have little faith in extension. & $35(28.5 \%)$ & $44(35.8 \%)$ & $29(23.6 \%)$ \\
\hline $\begin{array}{l}\text { 9. Asking public extension systems to achieve cost-recovery is an } \\
\text { attempt to weed them out. }\end{array}$ & $61(49.6 \%)$ & $33(26.8 \%)$ & $15(12.2 \%)$ \\
\hline 10. Extension's relevance is being questioned. & $46(37.4 \%)$ & $51(41.5 \%)$ & $12(9.8 \%)$ \\
\hline 11. Extension's competence is being questioned. & $45(36.6 \%)$ & $53(43.1 \%)$ & $11(8.9 \%)$ \\
\hline 12. Frequent extension reorganization is a sign of distrust. & $37(30.1 \%)$ & $48(39.0 \%)$ & $16(13.0 \%)$ \\
\hline
\end{tabular}

More than 60 percent of respondents agreed that financial support for extension has declined. Eighty-eight respondents (or $71.5 \%$ ) of those surveyed said that a professional extension organization would improve extension performance. Still many more respondents agreed that a professional organization would protect the interests of extension workers. Interestingly, a large number of respondents did not feel that extension's relevance, competence or reputation is being questioned.

\subsection{Perceptions of NGO Extension Workers}

The number of extension workers deserting the public extension sector for greener pastures in NGO organizations have been on the rise leading to questions such as whether NGO extension exists at the expense of public extension workers. The vast majority of respondents, 76 (61.8\%), felt that NGO extension duplicates the activities of public sector extension. Also, 73 respondents or about $60 \%$ felt that international donor agencies prefer to finance private over public extension systems. However, there is a strong disagreement that extension workers in NGOs perform better than their public sector counterparts. Surprisingly, extension workers believed that there was no way of assessing the effectiveness of NGO extension which begs the question: how should the effectiveness of NGOs be measured?

Table 6. Public extension workers' perception of their counterparts in NGOs

\begin{tabular}{llll}
\hline Item & Agree & Disagree & Not Sure \\
\hline $\begin{array}{l}\text { 1. Nongovernmental organizations (NGOs) duplicate the work of } \\
\text { agricultural extension workers. }\end{array}$ & $76(61.8 \%)$ & $20(16.3 \%)$ & $10(8.1 \%)$ \\
2. International donors prefer working through NGOs. & $73(59.3 \%)$ & $24(19.5 \%)$ & $11(8.9 \%)$ \\
3. NGOs like to cooperate with public extension workers. & $71(57.7 \%)$ & $30(24.4 \%)$ & $6(4.9 \%)$ \\
$\begin{array}{l}\text { 4. There is a need for NGOs and public sector extension to work } \\
\text { together. }\end{array}$ & $64(52.0 \%)$ & $34(27.6 \%)$ & $7(5.7 \%)$ \\
5. NGOs take away funding that should be going to public extension. & $59(48.0 \%)$ & $32(26.0 \%)$ & $17(13.8 \%)$ \\
6. NGO competition brings out the best in public sector extension. & $57(46.3 \%)$ & $38(30.9 \%)$ & $12(9.8 \%)$ \\
7. NGOs perform better than public section extension. & $34(27.6 \%)$ & $57(46.3 \%)$ & $17(13.8 \%)$ \\
8. There is no way of assessing the impact of NGOs in development. & $23(18.7 \%)$ & $57(46.3 \% 0$ & $21(17.1 \%)$ \\
\hline
\end{tabular}

\section{Discussion}

As we noted in the introduction, the United Nations predicts that the world population will reach almost 10 billion by 2050 and the bulk of this growth will occur in Africa. Above all, Africa's population growth is 
occurring among those least able to feed themselves-subsistence farm families who account for more than 70 percent of the African population. These are farmers who are supposed to feed their nations yet are unable to feed themselves. Africa's youth are also facing unique pressures due to the lack of employment opportunities. The majority of youth are located in rural areas where agriculture has the potential to provide employment opportunities. However, many migrate to urban areas as they find the subsistence farming their parents and grandparents endure to be too drudging. Contrary to popular opinion, Africa's youth are interested in farming as an occupation; however, what they seek is a modern, technology-based agriculture, for which their governments must assist them.

Additionally, growing population pressure is leading to the further dwindling of farm sizes to tiny units. Nevertheless, research shows that subsistence farmers are producing at a third of their capacity meaning that through intensive cultivation, using high value crops, they can double or even triple productivity and incomes. In essence, the goal is to turn subsistence farmers into small-scale, commercial entrepreneurs.

Agricultural extension, especially public sector extension, is crucial to transforming subsistence agriculture in Africa. However, as we have noted in this study, extension workers face many challenges, many of which African governments are unable to identify and address. In particular, extension workers have to envision their role, establish and protect their reputation and find ways to ensure self-satisfaction. In a nutshell, extension workers are required to facilitate integrated rural development programs and the sooner they understand this task the better they will be to take their place in development programming. In particular, development programs have grown in sophistication-from piecemeal to integrated or national poverty reduction programs. Extension workers must have the training to cope with the growing complexity of rural development programming.

Therefore, we propose a need for a professional association, which is best qualified to investigate extension training needs across the continent and to provide training that will increase the knowledge and competencies extension workers need. A professional association is also linked to honesty and integrity and can help improve the negative image of extension in many countries. Furthermore, it is not uncommon for extension workers to use public time for private gain. A professional association will ensure that extension workers are duly committed and accountable to farmers. Respondents agreed that a professionalism of extension would enhance their performance and even allow them to find ways to make extension financially self-sustaining. In the last few years, a small group of African extension scholars have formed an association called ExtensionAfrica, which can serve as the new professional extension organization. Our study has found that many extension agents at the grassroots would join such an organization if the membership fee is reasonable. They also agreed that ExtensionAfrica magazine, published 3-4 times a year, can be an effective tool for sharing knowledge among members across the continent on best practices. Such a magazine an also be financially self-sustaining through advertising.

\section{Conclusion and Recommendations}

The Economist magazine (2014) has noted that Africa is the fastest growing continent in the world due to its high fertility rate (the number of children a woman can have in her child bearing years). The fertility rate for Africa is an average of 4.7 children/women compared to 2.0 in the U.S. and 1.7 in South East Asia. Ironically, this population growth is occurring in the rural areas and among subsistence farmers who do not produce enough to feed themselves, much less, their respective nations. Therefore, population growth is outstripping food production in Africa resulting in huge food imports, which rose from US\$14 billion in the 1980s to more than US $\$ 22$ billion by 2007 (Rakpotoarisoa, Lafrate \& Paschali, 2012).

It is gratifying that African governments are increasingly committing more and more resources to agriculture, especially the subsistence sector, such as under the CAADP. However, there is no question that the challenge to agricultural transformation rests with extension, which is central to smallholder farmers' development. Our study found that forming a professional association for extension in Africa is key to improving extension effectiveness. Extension workers felt that a professional organization would provide more than just financial benefits for extension workers such as recognition among their members and the opportunity to learn from peers. More than 70 percent of respondents acknowledged that extension is the engine of agricultural and national development and that there is need to give extension the professionalism it deserves. Our conviction is that the African Forum for Agricultural Advisory Services (AFAAS), which is mandated by African governments to improve their extension services, can benefit from a partnership with ExtensionAfrica.

A professionalism of extension in Africa has the promise and potential to improve extension effectiveness and should be explored. Also, it will inject a scientific approach to extension rather than the current haphazard approach where each country pursues its own conviction of what extension should be or do. Several countries 
have begun forming their own extension policies but the question is whether varying extension policies can really lead to transforming extension? Clearly, our sample was too small to draw major conclusions and make key recommendations. Instead we urge the replication of the study to see if the need for a continent-wide professional association for extension holds true. Meanwhile we are convinced that ExtensionAfrica has a major role to play in strengthening extension in Africa.

\section{Acknowledgments}

This research was made possible through a grant from the U.S. Department of State to implement a project on "Increasing Capacity for Undergraduate Study Abroad in Ethiopia." However, the authors take responsibility for any issues and/or errors potentially arising from the study. The authors are also grateful to Dr. Fassil Kebede, Professor of Soil Science and Dean, Faculty of Agriculture, University of Gondar, Ethiopia who made transportation and other resources available for the data collection.

\section{References}

Amoako-Tuffour, J., \& Armah, B. (Eds.). (2008). Poverty reduction strategies in action: Perspectives and lessons from Ghana. Lanham, MD: Lexington Books.

Beegle, K., Christiaensen, L., Dabalen, A., Gaddis, I. (2016). Poverty in a Rising Africa (Report). Retrieved from https://doi.org/10.1596/978-1-4648-0723-7

Belay, K., \& Abebaw, D. (2004). Challenges facing agricultural extension agents: A case study from South-Western Ethiopia. African Development Review, 16(1), 139-168. https://doi.org/10.1111/j.1467-8268.2004.00087.x

Broderick, M. (2016). The Art of Managing Professional Services: Insights from Leaders of the World's Top Firms. Upper Saddle River, NJ: Pearson Prentice Hall.

Chapman, H. H. (1990). The profession of forestry and professional ethics. Journal of Forestry, 90(4), 14-17, 34.

Davidson, A. P., \& Ahmad, M. (2003). Privatization and the crisis of agricultural extension: The case of Pakistan. Burlington, VT: Ashgate Publishing Company.

From Limpopo, South Africa. Journal of Agricultural Science, 6(11), 1-7. https://doi.org/10.5539/jas.v6n11p1

Future Agricultures. (2010). The limits of decentralised governance: the case of agriculture in Malawi (Policy brief 033). Retrieved from

http://www.future-agricultures.org/policy-engagement/policy-briefs/814-the-limits-of-decentralised-governa nce-the-case-of-agriculture-in-malawi/file.

Gholami, R., Higón, D. A., Hanafizadeh, P., \& Emrouznejad, A. (2010). Is ICT the key to development? Journal of Global Information Management, 18(1), 66-83. https://doi.org/10.4018/jgim.2010091104

Inagaki, N. (2007). Communicating the impact of communication for development: recent trends in empirical research. Washington, D.C.: The World Bank. https://doi.org/10.1596/978-0-8213-7167-1

Lindblad, M. (n.d.). Five Keys to Professionalism in the Workplace. Retrieved from http://oureverydaylife.com/five-keys-professionalism-workplace-28133.html.

Lwoga, E. T., \& Ngulube, P. (2008). Managing indigenous and exogenous knowledge through information and communication technologies for agricultural development and achievement of the UN Millennium Development Goals in Tanzainia. In B. Njobvu \& S. Koopman (Eds.), Libraries and information services towards the attainment of the UN Millennium Development Goals (pp.73-88). Berlin: Walter de Gruyter.

Mittal, S., Gandhi, S., \& Tripathi, G. (2010). Socio-Economic Impact of Mobile Phones on Indian Agriculture (Working paper No. 246). Retrieved from http://test.icrier.org/pdf/WorkingPaper246.pdf.

Norton, A. (2010). 10 things that define a true professional. Retrieved from http://www.techrepublic.com/blog/10-things/10-things-that-define-a-true-professional/.

Oyaro, K. (2010). Africa: Agricultural Extension work both important and undervalued. Retrieved from http://ipsnews.net/print.asp?idnews=42143.

Qamar, M. K. (2005). Modernizing national agricultural extension systems: A practical guide for policy-makers of developing countries (Report). Retrieved from ftp://ftp.fao.org/docrep/fao/008/a0219e/a0219e00.pdf.

Rakotoarisoa, M. A., Lafrate, M., \& Paschali, M. (2012). Why Has Africa Become a Net Food Importer? Explaining Africa Agricultural and Food Trade Deficits (Report). Retrieved from http://www.fao.org/docrep/015/i2497e/i2497e00.pdf. 
Republic of South Africa. Ministry of Agriculture, Forestry \& Fisheries. (2011). National framework for extension recovery plan. Pretoria, South Africa: Department of Agriculture, Forestry \& Fisheries Communications Services.

Röling, N. (1972). Determining the Level of Agricultural Development in Tetu Sub-locations: Towards Measuring Extension Impact (Working paper No. 33). Narobi, Kenya: University of Nairobi Institute of Development Studies.

Röling, N., \& Jiggins, J. (2007, December). Making Trans-Disciplinary Science Work for Resource-Poor Farmers. Paper presented at the Farmer First Revisited Conference, University of Sussex, Brighton, England. Abstract retrieved from http://www.future-agricultures.org/farmerfirst/files/T2b_Roling.pdf.

Ronald, B. F. Dulle, \& Honesta, N. (2014). Assessment of the information needs of rice farmers in Tanzania: A case study of Kilombero District, Morogoro. Sokoine University of Agriculture, Tanzania. University of Nebraska - Lincoln DigitalCommons@University of Nebraska - Lincoln

Rondinelli, D. A. (1993). Development projects as policy experiments: An adaptive approach to development administration. New York, NY: Routledge.

Rutatora, D. F., \& Mattee, A. Z. (2001). Major Agricultural Extension Providers In Tanzania. African Study Monographs, 22(4), 155-173, December 2001 155, Centre for Sustainable Rural Development, Sokoine University of Agriculture Centre for Sustainable Rural Development, Sokoine University of Agriculture. http://www.tanzaniagateway.org/docs/major_agricultural_extension_providers_in_tanzania.

Schiffman, L. G., \& Kanuk, L. L. (1997). Consumer behavior. London: Prentice Hall.

Smith, R. (2014). Strategic Planning for Public Relations. New York, NY: Routledge.

The Economist. (2014). Fertility treatment. Retrieved from http://www.economist.com/news/leaders/21598648-birth-rates-are-not-falling-africa-fast-they-did-asia-mor e-contraception-would.

Vijayaragavan, K., \& Singh, Y. P. (1997). Managing human resources within extension. In B.E. Swanson, R.P. Bentz, \& A.J. Sofranko (Eds.), Improving Agricultural Extension: A Reference Manual. Retrieved from https://pdfs.semanticscholar.org/29a3/002197653ce8464cbc92bd4290d070c219d6.pdf.

West, B. C., Drake, D., \& Londo, A. (2009). Extension: A Modern-Day Pony Express? Journal of Extension, $47(2)$.

Zwane, E. (2014). The Role of Extension as a Profession Is Critical in Delivering Excellent Services: An Experience

\section{Copyrights}

Copyright for this article is retained by the author(s), with first publication rights granted to the journal.

This is an open-access article distributed under the terms and conditions of the Creative Commons Attribution license (http://creativecommons.org/licenses/by/3.0/). 